\title{
O agir de Deus nos Andes: diálogo e missão com os quéchuas
}

\author{
Orientador: Mario de França Miranda \\ Doutorando: David Mesquiati de Oliveira \\ Área de Concentração: Teologia Sistemático-Pastoral \\ Linha de Pesquisa: Fé e Cultura
}

Urge, em um mundo onde a pluralidade é percebida com mais intensidade, discutir novos parâmetros para a prática missionária. Os contextos indígenas, que veem de um longo processo de resistência aos modelos tradicionais de evangelização, despontam no novo cenário religioso, não mais como destinatários da salvação, mas como portadores da revelação, reivindicando critérios baseados na alteridade, diversidade e diálogo. É preciso repensar como comunicar a fé em Jesus Cristo e sua salvação em uma cultura específica, dado que o tão aclamado processo de globalização é ambíguo, pois, pese a tentativa de produzir uma homogeneidade cultural, tem gerado, paradoxalmente, movimentos identitários organizados e pulverizados, de distintas matizes. É o caso da cultura quéchua, que, para alguns, está em processo de desaparecimento, e, para outros, está se reinventando. Como estabelecer um diálogo entre essas minorias e a fé cristã, com vistas a um amadurecimento do processo de inculturação em curso? Quais seriam os elementos revelacionais na cultura quéchua e como enriqueceriam o cristianismo como expressão da fé cristã? Essas foram algumas perguntas que nortearam esta tese. Não temos a pretensão de resolver todo o processo de inculturação da fé entre os quéchuas. Mas buscamos contribuir para o diálogo e a missão entre os quéchuas, aprofundando a reflexão sobre as consequências do encontro entre o Evangelho e as culturas, no sentido de reconhecer as riquezas da cultura e da religião local como provenientes de Deus e torná-las comuns a todos. Esta tese busca ser uma contribuição e reconhecimento ao esforço da teologia índia, refletindo sobre a inculturação entre os quéchuas, ao mesmo tempo em que se revela uma defesa e uma valorização das culturas autóctones indígenas. A tese foi organizada em três grandes capítulos com subdivisões demarcadas. O primeiro capítulo gira em torno do eixo histórico-cultural quéchua. Apresenta a riqueza da 
cultura e as especificidades da religião quéchua, tendo a festa Inti Raymi como pano de fundo e expressão de fé. Expõe as categorias do pensamento andino e como os quéchuas estruturam seu Cosmos (Pacha). O segundo capítulo, propõe uma teologia cristã que favoreça o diálogo e o reconhecimento revelacional de Deus nas culturas e nas religiões. Gira em torno do eixo teológico. O terceiro, gira em torno do eixo dialógico-missionário. Analisa como seria missionar entre os quéchuas a partir dessa matriz dialogal, evangelizando e sendo evangelizado pelo outro. Inculturar é, também, dialogar com as bases religiosas de outra cultura.

Palavras-chave: Teologia, missão, inculturação. 